\title{
Safety Performance Index pada Industri Batik Tulis Berdasarkan Kriteria Majemuk
}

\author{
Nachnul Ansori $^{1^{*}}$, Trisita Novianti ${ }^{1}$, Fitri Agustina $^{1}$, Nur Rakhmawati $^{1}$
}

\begin{abstract}
Accident generally occurs due to the activities which is done in unsafe conditions or even unsafe behavior. These conditions can influence workers productivity. In batik industries, those workers use toxic material and work in non ergonomic atmosphere. Moreover, they also do not care of the environment and do not use personal protective equipments (PPE). Workers at Madura batik SMEs have not fully realized the significancy of the occupational health and safety (OHS) in their working areas. Therefore, the aims of this research is to evaluate OHS performance based on the indicators of safety performance index (SPI), which is multicriteria, in that industri. The safety performance attributes were obtained from the factor analysis. The index is calculated based on the weighted evaluation results of critical behavior checklist (CBC), integrated with analytical hierarchy process (AHP). As the results, we should give priority to improve the knowledge and experience toward OHS of the workers and also improve the working environment of the Madura's batik industries. Additionally, the performance of OHS in coloring process is also on the threshold of unsafe condition, further development on the coloring process is needed.
\end{abstract}

Keywords: Safety behavior, OHS, creative industry, SPI, CBC, AHP.

\section{Pendahuluan}

Potensi bahaya kerja (hazard) selalu ada diseluruh rangkaian aktifitas pekerjaan (Makin dan Winder [1]), demikian halnya dengan pekerja di Industri Kecil Menengah (IKM) Batik Tulis Madura. Pada proses pembuatan batik, pekerja harus berhadapan dengan banyaknya potensi bahaya kerja baik yang dipicu oleh kondisi kerja yang tidak aman (unsafe condition), aktifitas yang tidak aman (unsafe action) ataupun bahkan prilaku tidak aman (unsafe behavior) seperti rasa panas yang didapatkan dari tungku pembakaran saat proses pewarnaan dan proses pembuatan motif dengan malam, posisi kerja yang tidak ergonomis, serta kontak dengan bahan kimia dan bahan pewarna yang digunakan yang notabene menggunakan zat pewarna tekstil yang berbahaya (Agustina dan Maulana [2]).

Penelitian terkait fasilitas kerja IKM batik (Agusti [3]) menyebutkan bahwa ruang dan peralatan kerja yang digunakan selama proses pembatikan di IKM pada umumnya masih terkategori tidak ergonomis. Hal ini disebabkan oleh fasilitas kerja yang tidak mempertimbangkan kebutuhan kapasitas kemampuan kerja pekerja. Hal ini disebabkan oleh fasilitas kerja yang tidak mempertimbangkan kebutuhan kapasitas kemampuan kerja pekerja, misalnya tempat duduk, gawangan dan lingkungan kerja kerja fisik seperti tingkat pencahayaan, suhu dan kondisi lingkungan

${ }^{1}$ Fakultas Teknologi Industri, Program Studi Teknik Industri, Universitas Trunojoyo, Jl. Raya Telang, PO Box 2, Bangkalan Madura 69192, Indonesia. Email: nachnul@gmail.com

* Penulis korespondensi kerja yang terkesan sangat kumuh. Ditambah lagi informasi lain oleh lembaga Clean Batik Initiative Centre ([4, 5, 6]), umumnya bahan kimia yang digunakan dalam industri batik diantaranya adalah Soda Api $(\mathrm{NaOH})$, Asam Klorida (HCL), Sodium Nitrit $\left(\mathrm{NaNo}_{2}\right)$, Hidrogen Peroksida $\left(\mathrm{H}_{2} \mathrm{O}_{2}\right)$, Sodium Ditionit $\left(\mathrm{Na}_{2} \mathrm{~S}_{2} \mathrm{O}_{4}\right)$, Sodium Karbonat $\left(\mathrm{Na}_{2} \mathrm{CO}_{3}\right)$, Sodium Silikat $\left(\mathrm{Na}_{2} \mathrm{SiO}_{3}\right)$ serta bahan pewarna Naftol. Material tersebut merupakan bahan kimia yang tergolong B3 (Bahan Berbahaya dan Beracun), sehingga perlakuan/penanganan terhadap material tersebut harus mempertimbangkan prosedur kerja yang baik (Syamwil et al. [7]). Bahan B3 apabila terjadi kontak langsung dengan kulit dapat menyebabkan rasa terbakar pada kulit, alergi dan apabila kontak langsung terus terjadi dalam jangka waktu yang panjang akan menyebabkan penyakit dan efek yang kronis.

IKM Batik Tulis Madura pada proses produksinya masih menggunakan peralatan kerja yang relatif sederhana dengan teknik dan proses pengerjaan yang secara turun temurun diajarkan tanpa adanya perubahan prosedur maupun inovasi (Agustina dan Maulana [2]). Teknik pengerjaan batik yang selama ini dilakukan cenderung masih tidak memperdulikan aspek keselamatan dalam bekerja. Pekerja bekerja dengan kondisi lingkungan yang tidak bersih dan tidak tertata, alat dan bahan baku produksi tidak simpan dan ditata setelah digunakan. Air limbah sisa pewarnaa dan pelorodan batik tidak dikelola dengan baik dan dibiarkan tercecer dan mengalir di lantai kerja tanpa adanya saluran pembuangan yang aman. Bahan-bahan kimia yang digunakan 
tidak diberi label tetapi hanya dihafalkan dengan melihat bentuk dan warnanya, sehingga kebiasaan/ budaya/prilaku ini sangat berisiko terhadap keselamatan dan kesehatan pekerja. Tidak adanya pengawasan serta kurangnya pemahaman penggunaan bahan kimia membuat pekerja terkesan tidak mempedulikan kadar dan takaran yang sesuai, sehingga proses pencampuran bahan-bahan kimia dilakukan tanpa menggunakan standar/ acuan sehingga komposisi takarannya tidak sama. Kurangnya pengawasan prosedur kerja, menjadikan pekerja melakukan kegiatan kerja sesuai dengan persepsi masingmasing dan tidak berhati-hati sehingga sangat dimungkinkan potensi bahaya muncul oleh karena prilaku pekerja yang tidak aman (unsafe behavior).

Tujuan yang ingin dicapai dari penelitian ini adalah mengevaluasi kinerja K3 melalui indikator safety performance index dengan mempertimbangkan kriteria terbobot pada critical behavior checklist (CBC).

\section{Metode Penelitian}

Behavior based safety (BBS) merupakan metode yang memiliki prinsip pelibatan motivasi, bantuan dan keberlanjutan prilaku selamat dalam bekerja (Health and Safety Authority [8]). BBS dipilih oleh karena efektif dalam pelibatan peningkatkan keselamatan kerja antara manajemen dan tenaga kerja, persepsi, umpan balik, tanggung jawab, termasuk di dalamnya adalah pengukuran performansinya (De Pasquale dan Geller [9]). Kualitas implementasi BBS tidak pada program, namun pada proses pengelolaan terintegrasi untuk peningkatan keselamatan, kesehatan dan aktifitas lingkungan (Hurst dan Palya [10]). Penelitian ini dilakukan dengan menggunakan kuesioner critical behavior checklist (CBC) untuk menentukan safety performance index (SPI). Pada kuisioner ini akan ditentukan target prilaku berdasarkan kondisi industri yang diamati (Al-Hemoud dan Al-Asfoor [11]). Selain itu diberikan juga kuesioner perbandingan berpasangan analitical hirarchy process (AHP) untuk kriteria majemuk yang diintegrasikan pada pengukuran indikator SPI.

Populasi dalam penelitian ini adalah pekerja pada IKM batik yang ada di Kabupaten Bangkalan. Berdasarkan data yang diperoleh dari Dinas Perindustrian dan Perdagangan (DISPERINDAG) Kabupaten Bangkalan, diperoleh sebelas IKM batik dengan kriteria memiliki keseluruhan proses produksi (mulai dari persiapan motif, kain, pembatikan hingga pengeringan). Total jumlah pekerja yang tersebar di sebelas IKM adalah 50 pekerja. Pengambilan data dalam penelitian ini dilakukan sebanyak dua tahapan, dimana pada tahapan pertama dengan kuesioner critical behavior checklist (CBC) yang disebarkan pada semua pekerja. Pada tahap pengumpulan data kedua dengan kuesioner perbandingan berpasangan AHP dengan Expert System, yakni penilaian dari responden ahli, dalam hal ini adalah ahli dari dinas koperasi dan UMKM, DISPERINDAG Kabupaten Bangkalan Madura serta pemilik usaha.

\section{Kuisioner Target Prilaku}

Kuesioner CBC merupakan kuesioner yang digunakan untuk menilai sikap pekerja saat melakukan kegiatan kerja apakah tergolong sikap aman (safety behavior) atau sikap tidak aman (unsafe behavior) (Al-Hemoud dan Al-Asfoor [11]). Dari hasil penilaian dengan CBC akan dilakukan pengukuran SPI. Kuesioner CBC akan dinilai dengan menggunakan skala likert dimana jawaban responden terhadap pernyataan yang diajukan terbagi menjadi 5 jawaban yang memiliki tingkatan nilai seperti pada Tabel 1.

Pernyataan positif seperti pada Tabel 1 dalam penelitian ini diidentifikasikan sebagai safety behavior sedangkan pernyataan negatif diidentifikasi sebagai unsafe behavior.

\section{Kuesioner Hubungan Berpasangan-Pairewise Questiannaire}

Variabel-variabel yang akan dinilai dengan kuesioner hubungan berpasangan adalah variabel yang terbentuk dari hasil analisis faktor, berikut adalah rancang kuesioner hubungan berpasangan dengan AHP. Skala penilaian yang digunakan dalam kuesioner AHP adalah 1-9 dimana nilai-nilai tersebut memiliki arti seperti dijelaskan pada Tabel 2.

\section{Pengukuran Safety Performance Index (SPI)}

Pada tahapan ini dilakukan pengukuran terhadap kinerja perilaku pekerja dengan melihat nilai rasio antara sikap aman hasil observasi (safe observed) dengan total sikap observasi (total observed). Nilai safe observed dan total observed diperoleh dengan mengintegrasikan BBS dan AHP. Hal ini bertujuan agar penilaian kinerja perilaku yang didapatkan tidak hanya berdasar penilaian perilaku kerja hasil kuesioner Critical behavior checklist (CBC) pada metode BBS tetapi juga dengan mempertimbangkan bobot kepentingannya yang diperoleh dari metode AHP. Diharapkan nilai kinerja perilaku dapat menggambarkan keadaan sebenarnya yang ada di industri batik. Pelaksanaan observasi lapangan, analisis serta komunikasi pada prilaku tidak selamat membantu pekerja menyadari risiko prilaku tidak aman serta mampu meningkatkan sasaran pencapaian pencegahan sekaligus pengurangan prilaku yang tidak aman (Tosolin [14]). 
Tabel 1. Skala likert pernyataan positif dan negatif (Heliani [12])

\begin{tabular}{lcc}
\hline Pernyataan & $\begin{array}{c}\text { Skor untuk } \\
\text { pernyataan } \\
\text { positif }\end{array}$ & $\begin{array}{c}\text { Skor untuk } \\
\text { pernyataan } \\
\text { negatif }\end{array}$ \\
\hline Selalu & 5 & 1 \\
Sering & 4 & 2 \\
Kadang-kadang & 3 & 3 \\
Hampir & 2 & 4 \\
Tidak Pernah & 1 & 5 \\
\hline
\end{tabular}

Tabel 2. Skala penilaian kuesioner AHP (Saaty [13])

\begin{tabular}{|c|c|c|}
\hline $\begin{array}{c}\text { Tingkat } \\
\text { kepentingan }\end{array}$ & Definisi & Penjelasan \\
\hline 1 & Sama pentingnya & $\begin{array}{l}\text { Dua kegiatan memiliki } \\
\text { kontribusi yang sama } \\
\text { terhadap tujuan }\end{array}$ \\
\hline 2 & $\begin{array}{l}\text { Hubungan yang } \\
\text { lemah }\end{array}$ & \\
\hline 3 & $\begin{array}{l}\text { Kepentingan } \\
\text { yang sedang }\end{array}$ & $\begin{array}{l}\text { Pengalaman dan } \\
\text { penilaian sedikit } \\
\text { mendukung satu } \\
\text { kegiatan di atas yang lain }\end{array}$ \\
\hline 4 & $\begin{array}{l}\text { Kepentingan } \\
\text { yang lebih dari } \\
\text { pada sedang }\end{array}$ & \\
\hline 5 & $\begin{array}{l}\text { Kepentingan } \\
\text { yang kuat }\end{array}$ & $\begin{array}{l}\text { Pengalaman dan } \\
\text { penilaian sangat } \\
\text { mendukung satu } \\
\text { kegiatan di atas yang lain }\end{array}$ \\
\hline 6 & $\begin{array}{l}\text { Kepentingan } \\
\text { yang lebih kuat }\end{array}$ & \\
\hline 7 & Sangat kuat & $\begin{array}{l}\text { Suatu kegiatan sangat } \\
\text { disukai dari pada yang } \\
\text { lain dan mendominasi }\end{array}$ \\
\hline 8 & $\begin{array}{l}\text { Sangat-sangat } \\
\text { kuat }\end{array}$ & \\
\hline 9 & $\begin{array}{l}\text { Kepentingan } \\
\text { yang ekstrim }\end{array}$ & $\begin{array}{l}\text { Adanya bukti } \\
\text { menegaskan suatu } \\
\text { kegiatan mutlak } \\
\text { diurutan tertinggi }\end{array}$ \\
\hline
\end{tabular}

Tabel 3. UKM dan jumlah kerja

\begin{tabular}{clc}
\hline No & \multicolumn{1}{c}{ Nama IKM } & $\begin{array}{c}\text { Jumlah pekerja } \\
\text { (orang) }\end{array}$ \\
\hline 1 & Zulpah Batik Madura & 2 \\
2 & Batik Su'udiyah & 4 \\
3 & Batik Sumber Rejeki & 9 \\
4 & Batik Tulis Rusli & 5 \\
5 & Batik Rofiah & 3 \\
6 & Batik Mubarok & 10 \\
7 & Batik Wijaya & 5 \\
8 & Batik Ajis & 4 \\
9 & Batik Alya & 6 \\
10 & Batik Noval & 1 \\
11 & Batik Bunda Ummiyah & 1 \\
\hline & Total & 50 \\
\hline
\end{tabular}

Menurut (Al-Hemoud dan Al-Asfoor [11]) penilaian kinerja perilaku dapat dinotasikan dengan SPI. Penilaian dilakukan dengan persamaan berikut:

$$
\begin{aligned}
& \text { SPI } \\
& =\frac{\text { safeobserved }}{\text { safeobserved }+ \text { At }- \text { Risk(unsafeobserved })} \times 100 \%
\end{aligned}
$$

Formulasi yang digunakan dalam penilaian kinerja perilaku baik berupa SPI. Pengukuran dilakukan dengan menentukan rasio safe observation terhadap total observation dimana dalam persamaan SPI total observation diuraikan menjadi safe observation dan at-risk. Apabila kedua nilai observation tersebut dijumlahkan akan menjadi total observation.

\section{Hasil dan Pembahasan}

Proses keseluruhan dalam menghasilkan selembar kain batik terdiri dari pembuatan desain atau pola di kertas oleh pemilik usaha, pembuatan pola batik di kain yang dikerjakan oleh tenaga kerjanya dan memiliki proses pewarnaan, penutupan pola dan pelorodan malam. Pengamatan yang dilakukan pada usaha batik yang meliputi keseluruhan proses pengerjaan. Tabel 3 menunjukkan terdapat sebelas IKM batik yang diobservasi sedangkan proses yang diamati adalah proses pewarnaan dan pelorodan batik, mengingat potensi bahaya yang ada pada proses tersebut.

Tabel 3 juga menunjukkan jumlah tenaga kerja yang dimiliki oleh masing-masing IKM. Terdapat sejumlah 50 tenaga kerja pewarnaan dan pelorodan yang menjadi responden dalam penelitian. Kedua proses produksi tersebut itu dikerjakan oleh orang yang sama. Penilaian dilakukan dengan penyebarkan kuesioner CBC kepada keseluruhan pekerja tercacat sejumlah 50 orang pekerja bagian pewarnaan dan pelorodan.

Penskoran dilakukan pada ketujuh faktor yang terdiri dari faktor penanganan limbah, kondisi kerja, alat pelindung diri, fasilitas kerja, pengawasan, tingkat kenyamanan dan pengetahuan/pengalaman dengan menggunakan skala penskoran seperti pada Tabel 1. Jika indikator pertanyaan berupa pernyataan negatif (justifikasi aman), maka skor menggunakan penilaian positif. Demikian sebaliknya bila indikator pertanyaan berupa pernyataan negatif (justifikasi tidak aman), maka skor menggunakan penilaian negatif. 


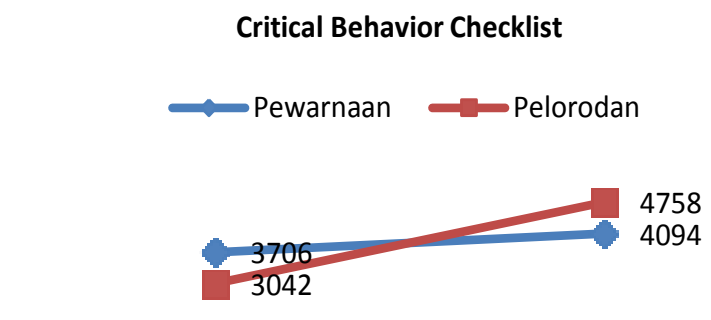

safe

at-risk

Gambar 1. Hasil Kuisioner CBC

Tabel 4. Hasil skoring faktor

\begin{tabular}{|c|c|c|c|c|c|c|}
\hline \multirow{2}{*}{ Faktor } & \multicolumn{2}{|c|}{$\begin{array}{l}\text { Pewarnaan, } \\
\text { SPI 0,48 }\end{array}$} & \multirow{2}{*}{ SPI } & \multicolumn{2}{|c|}{$\begin{array}{c}\text { Pelorodan, SPI } \\
0,39 \\
\end{array}$} & \multirow{2}{*}{ SPI } \\
\hline & Safe & $\begin{array}{l}\text { At- } \\
\text { risk }\end{array}$ & & Safe & $\begin{array}{l}\text { At- } \\
\text { risk }\end{array}$ & \\
\hline $\begin{array}{l}\text { Penanganan } \\
\text { limbah (F1) }\end{array}$ & 288 & 612 & 0,32 & 281 & 619 & 0,31 \\
\hline $\begin{array}{l}\text { Kondisi kerja } \\
\text { (F2) }\end{array}$ & 764 & 436 & 0,64 & 481 & 719 & 0,40 \\
\hline APD (F3) & 669 & 1131 & 0,37 & 443 & 1357 & 0,25 \\
\hline $\begin{array}{l}\text { Fasilitas } \\
\text { kerja (F4) }\end{array}$ & 495 & 405 & 0,55 & 477 & 423 & 0,53 \\
\hline $\begin{array}{l}\text { Pengawasan } \\
\text { (F5) } \\
\text { Tingkat }\end{array}$ & 329 & 271 & 0,55 & 185 & 415 & 0,31 \\
\hline $\begin{array}{l}\text { kenyamanan } \\
\text { (F6) }\end{array}$ & 354 & 246 & 0,59 & 368 & 232 & 0,61 \\
\hline $\begin{array}{l}\text { Pengetahuan } \\
\& \text { penga- } \\
\text { laman (F7) }\end{array}$ & 807 & 993 & 0,45 & 807 & 993 & 0,45 \\
\hline Total & 3706 & 4094 & & 3042 & 4758 & \\
\hline
\end{tabular}

Hasil kuisioner CBC (Gambar 1) diperoleh bahwa pekerja bagian pewarnaan batik tulis memiliki peri laku kerja aman (safe) dengan nilai 3706. Nilai ini diperoleh dari penjumlahan penskoran dari 26 indikator (Gambar 2) yang dilakukan oleh 50 orang pekerja sebagai obyek yang diamati, sedangkan perilaku tidak aman (At-Risk) sebesar 4094. Demikian juga pada pekerja bagian pelorodan memiliki perilaku aman (safe) 3042 dan perilaku tidak aman (At-Risk) sebesar 4758. Jika dilihat dari total nilai observasi (7800), terlihat total nilai At-Risk yang menunjukkan perilaku unsafe lebih besar dibandingkan dengan nilai safe. Perolehan skor pada bagian pewarnaan prilaku tidak aman memiliki nilai yang lebih besar dari prilaku aman (at-risk, $4094>$ safe, 3706), demikian juga bagian pelorodan didapatkan nilai prilaku kerja tidak aman lebih besar dari pada aman (at-risk, $4758>$ safe, 3042). Hal ini mengindikasikan pekerja bagian pewarnaan dan pelorodan lebih banyak melakukan tindakan dan perilaku tidak aman dalam bekerja dibandingkan dengan tindakan aman saat bekerja.

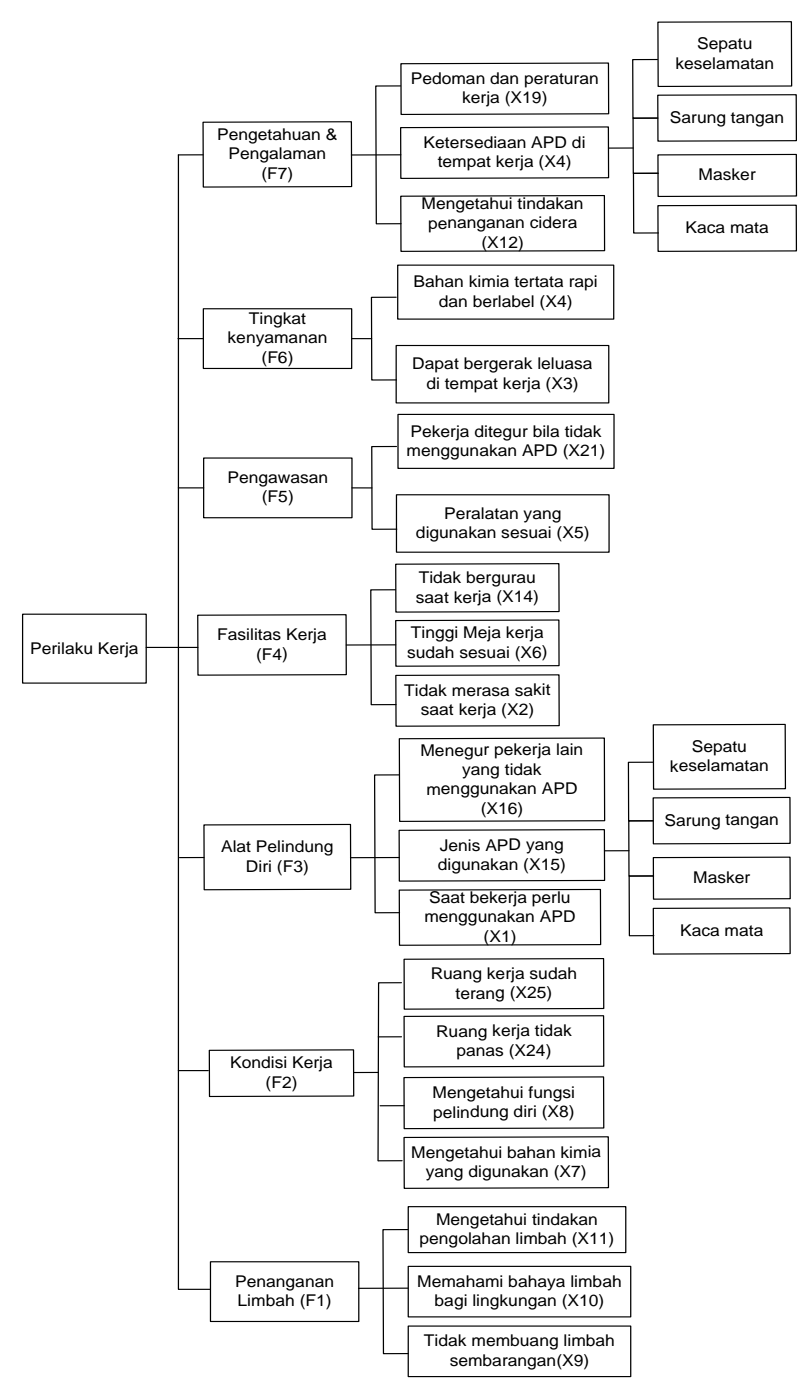

Gambar 2. Hirarki kriteria dan sub kriteria

Tabel 5. Bobot antar kriteria

\begin{tabular}{lcc}
\hline \multirow{2}{*}{ Faktor } & \multicolumn{2}{c}{ Bobot kepentingan } \\
\cline { 2 - 3 } & Pewarnaan & Pelorodan \\
\hline Penanganan limbah (F1) & 0,071 & 0,033 \\
Kondisi kerja (F2) & 0,253 & 0,218 \\
APD (F3) & 0,104 & 0,072 \\
Fasilitas kerja (F4) & 0,191 & 0,216 \\
Pengawasan (F5) & 0,041 & 0,065 \\
Tingkat kenyamanan (F6) & 0,098 & 0,131 \\
Pengetahuan dan & & \\
Pengalaman (F7) & 0,243 & 0,265 \\
\hline
\end{tabular}

Tabel 6. Hasil kinerja safety performance index

\begin{tabular}{lccc}
\hline \multicolumn{1}{c}{ Proces } & SPI & Min target, SPI & Selisih \\
\hline Pewarnaan & $50 \%$ & $>50 \%$ & $0 \%$ \\
Pelorodan & $41 \%$ & & $-9 \%$ \\
\hline
\end{tabular}

Adapun rincian hasil kusioner CBC beserta penilaian SPI pada dua proses bagian pewarnaan dan pelorodan dapat ditunjukkan pada Tabel 4. Pada perhitungan SPI, safe observed menunjukkan pada jumlah perilaku aman hasil temuan observasi dan At-Risk atau unsafe observed merupakan jumlah 
temuan perilaku yang tidak aman yang dilakukan saat melakukan aktivitas kerja. Adapun kriteria nilai SPI adalah jika SPI < 0,5 maka berimplikasi pada unsafe, SPI $=0,5$ bermakna rerata atau normal, sedangkan SPI > 0,5 mengindikasikan safe.

Dari ketujuh faktor perilaku yang dilakukan penilaian sebagaimana Tabel 4 dan Gambar 2. Tiga diantaranya mengindikasikan perilaku unsafe (nilai di bawah 0,50 atau 50\%) pekerja bagian pewarnaan yakni faktor penanganan limbah (F1), faktor APD (F3) dan faktor pengetahuan dan pengalaman (F7). Faktor yang teridentifikasi perilaku tidak aman pekerja bagian pelorodan adalah faktor penanganan limbah (F1), faktor kondisi kerja (F2), faktor APD (F3), faktor pengawasan (X5) serta faktor pengetahuan dan pengalaman (F7).

Kelemahan skor hasil penilaian belum mempertimbangkan hubungan tingkat pengaruh dari kepentingan masing-masing faktor maupun indikator. Oleh karenanya pada penilaian SPI dilakukan dengan mengintegrasikan hasil penskoran awal dengan mempertimbangkan tingkat pengaruh hubungan antar faktor dan indikator yang dibuat dalam bentuk hirarki faktor.

Konfigurasi hirarki kriteria majemuk permasalahan dalam penelitian dapat digambarkan dalam struktur hirarki dengan metode AHP (Gambar 2).

Hasil output bobot kepentingan diperoleh dengan menggunakan Expert Choice versi 2000 sebagaimana Tabel5.

Tabel 5 menunjukkan hasil pembobotan masingmasing faktor pada bagian pewarnaan dan bagian pelorodan. Dari hasil tersebut dapat diketahui bahwa pada bagian pewarnaan faktor yang memiliki bobot kepentingan paling tinggi adalah faktor kondisi kerja dengan bobot 25,3\% lebih penting dibandingkan dengan 6 faktor lainnya. Faktor dengan bobot kepentingan tertinggi kedua adalah faktor pengetahuan dan pengalaman dalam K3 sebesar 24,3\%, sedangkan faktor lainnya memiliki tingkat kepentingan yang rendah bila dibandingkan yanglain yakni kurang dari 20\%. Pada bagian pelorodan malam, indikator yang memiliki bobot kepentingan paling tinggi untuk dimiliki pekerja adalah pengetahuan dan pengalaman dalam K3 dengan bobot $26,5 \%$, faktor yang memiliki bobot kepentingan tertinggi kedua dan ketiga adalah kondisi kerja21,8\% dan fasilitas kerja dengan bobot 21,6\%. Faktor penanganan limbah, APD, pengawasan, tingkat kenyamanan menurut responden kurang penting dan hanya diberi bobot kurang dari $20 \%$. Selanjutnya dilakukan penskoran dengan mengintegrasikaan bobot nilai tingkat kepentingan pada kedua proses dengan penilaian SPI yang sebelumnya diperoleh dengan menggunakan CBC.

Hasil integrasi penilaian SPI dari CBC dengan AHP disajikan pada Tabel 6. Diperoleh nilai SPI pekerja bagian pewarnaan batik tulis sebesar sebesar 50\%. Nilai tersebut diperoleh dari penilaian SPI dengan mempertimbangkan bobot ketujuh faktor faktor. Berdasarkan kriteria SPI (Ningsih [15]), nilai SPI pekerja bagian pewarnaan sama dengan 50\% sehingga dapat dikatakan kondisi perilaku kerja pada bagian pewarnaan berada pada kondisi rerata atau level prilaku kerja aman yang terkategori sedang, namun nilai ini masih berada pada ambang batas kelayakan SPI, dimana target yang diharapkan adalah lebih dari 50\% (Wayne [16]).

Demikian juga dengan SPI pekerja bagian pelorodan batik tulis diperoleh $41 \%$. Melihat kriteria nilai SPI pekerja bagian pelorodan di bawah 50\%, dapat disimpulkan bahwa kondisi perilaku kerja di bawah rerata atau berada pada kondisi kurang baik. Nilai $41 \%$ pada SPI menunjukkan bahwa $41 \%$ pekerja bagian pelorodan belum memahami dan memiliki perilaku aman sesuai dengan indikasi perilaku dalam faktor penilaian. Selisih negatif $9 \%$ merupakan gap perilaku pekerja minimal yang harus dicapai sehingga perlu dilakukan peningkatan perbaikan untuk meningkatkan perilaku kerja ke aman.

Sementara, tinjauan hasil-hasil penelitian IKM di Denmark (Hasle et al. [17]) menyatakan bahwa dari kajian penelitian 1200 paper diantaranya 47\% mengkaji K3 pada industri kecil, dimana kinerja K3 disebabkan oleh 11\% budaya tempat kerja, 25\% dipicu oleh organisasi dan aktifitas, 30\% disebabkan oleh metode dan peralatan dan hanya sekitar 7\% disebabkan faktor regulasi dan pengawasan dan sisanya sekitar 3\% disebabkan oleh faktor ekonomi dan lingkungan. Ketersediaan peralatan kerja yang memadai dan sistem manajerial yang mencukupi sangat memungkinkan dilakukan di industri skala besar dengan dukungan dana dan sumber daya manuasia. Namun berbeda dengan kondisi yang dialami oleh IKM. Oleh karenanya (Kines dan Andersen [18]) dalam upaya peningkatan implementasi kinerja K3 di IKM, mencoba melakukan intervensi partisipasi prilaku pencegahan kecelakaan dengan pendekatan faktor budaya kerja melalui prilaku kerja. Hal ini sejalan dengan (Ansori [19, 20]) bahwa IKM dengan kondisi teknologi dan ketersediaan sumberdaya yang sangat sederhana, dari aspek pengetahuan dan kesadaran dalam K3 lebih efektif dilakukan dengan media membangun kesadaran berprilaku sehat dan selamat baik dari pekerja maupun pemilik usaha. Secara teknis (Xiongjun [21]) menyebutkan bahwa dibutuhkan prosedur teknis dalam pengelolaan prilaku aman 
yang ini dikarenakan kajian prilaku aman di IKM masih dalam tahapan eksplorasi.

\section{Simpulan}

Target prilaku pada CBC pekerja batik tulis Bangkalan pada proses pewarnaan maupun pelorodan masih terkategori berperilaku tidak aman. Kriteria majemuk yang paling dipentingkan pada pencapaian prilaku yang aman (safety behavior) pada proses pewarnaan berupa kondisi kerja, sedangkan pada proses pelorodan adalah kriteria pengetahuan dan pengalaman.

Hasil evaluasi kinerja K3 berdasarkan parameter SPI terintegrasi dengan AHPpada bagian pewarnaan dan pelorodan diperoleh hasil secara berturutturut sebesar $50 \%$ dan $41 \%$ yang mengindikasikan bahwa kondisi keselamatan kerja pada proses pewarnaan berada pada kondisi ambang batas minimal sedangkan pada proses pelorodan berada pada kinerja yang belum tercapai.

\section{Daftar Pustaka}

1. Makin, A. M and Winder, C., Managing Hazards in the Workplace using Organisational Safety Management Systems: A Safe Place, Safe Person, Safe Systems Approach, Journal of Risk Research, 12(3-4), 2009, pp. 329-343.

2. Agustina, F. dan Maulana, A., Analisis Postur Kerja dengan Tinjauan Ergonomi di Industri Batik Madura, Jurnal Inovasi dan Kewirausahaan: Kajian di Negara-negara berkembang, 11(3), 2012, pp. 167-171

3. Agusti, N., Perancangan Ulang Ruang dan Peralatan Kerja dengan Pendekatan Ergonomi Bagi Pembatik Tulis pada Pengrajin Batik Tulis $X$. Tesis, Fakultas Kesehatan Masyarakat Program Magister Keselamatan dan Kesehatan Kerja Universitas Indonesia, Depok, 2012.

4. Clean Batik Initiative Centre. Pedoman Penanganan Zat-zat Kimia, Tindakan Pencegahan dan Pertolongan Pertama, German-Indonesia Chamber of Industry and Commerce, 2011, available at http://cleanbatik.com/index.php?id=211.

5. Clean Batik Initiative Centre. Ho-2 Proses Pembuatan Batik. German-Indonesia Chamber of Industry and Commerce, 2011, available at http://cleanbatik.com/index.php?id=207.

6. Clean Batik Initiative Centre. Bahan Kimia Berbahaya dalam Pembuatan Batik, GermanIndonesia Chamber of Industry and Commerce, 2011, available at http://cleanbatik.com/index. php?id=207.

7. Syamwil, R., Kusumastuti, A., dan Nurrohmah, S. Peningkatan Kinerja Industri Batik Melalui Penerapan Standar Operation Procedure, Lingkungan, Serta Kesehatan dan Keselamatan
Kerja, Rekayasa, Jurnal Penerapan Teknologi dan Pembelajaran, 8(1), 2010, pp.30-36.

8. Health and Safety Authority, Behaviour Based safety Guide, The Metropolitan Building, James Joyce Street, Dublin 1, 2013.

9. DePasquale, J.P., Geller, E.S., Critical Success Factors for Behavior-Based Safety: A Study of Twenty Industry-wide Applications, Journal of Safety Research, 30 (4), 1999, pp. 237-249.

10. Hurst, P., and Palya, W., Selecting an Effective BBS Process: Fundamental Elements Should Guide Decision Making, Professional Safety, 48(9), 2003, pp. 39-43.

11.Al-Hemoud and Al-Asfoor, A Behavior Based Safety Approuch at a Kuwait Research Institution, Journal of Safety Research, 37, 2006, pp. 201-206.

12. Heliani, Pengaruh Sistem Pengendalian Manajemen terhadap Kinerja Manajerial dengan Gaya Kepemimpinan sebagai Variabel Moderating. Universitas Pendidikan Indonesia, 2012.

13. Saaty, T. L., Decision Making with The Analytic Hierarchy Process, International Journal of Service Sciences, 1(1), 20-08, pp.83-98

14. Tosolin F., Behavior-based Safety, Giornale Italiano di Medicina del Lavoro ed. Ergonomia 32, 2010, pp. A7-A12.

15. Ningsih, A. R., Evaluasi Pelaksanaan Behavior Based Safety pada Program STOP dalam Membentuk Perilaku Aman Tenaga Kerja di PT X Tahun 2013, Universitas Airlangga, 2013.

16. Wayne, D., An Analysis of the Behavior Based Safety Program at Company XYZ. A Research Paper - University of Wisconsin Stout, 2004.

17. Hasle, P., and Limborg, H. J., A Review of the Literature on Preventive Occupational Health and Safety Activities in Small Enterprises, Industrial Health, 44, 2006, pp. 6-12.

18. Kines, P., Andersen, D., Andersen, L. P., Nielsen, K., and Pedersen, L., Improving Safety in Small Enterprise through an Integrated Safety Management Intervention, Journal of Safety Research, 44, 2012, pp. 87-95.

19. Ansori, N., Novianti, T., Agustina F., dan Rakhmawati, N., Identifikasi Faktor pada Kinerja Prilaku Implementasi K3 Industri Batik Bangkalan. Prosiding Seminar Nasional Lemlit. UNM. Universitas Negeri Makasar, 2015, pp. 282-287.

20. Ansori, N., Novianti, T., Agustina F., dan Hasanah, T. U., Evaluasi Kesehatan dan Keselamatan Kerja (K3)UKM Batik Putra Madura Dengan Behavior Based Safety (BBS), Prosiding Seminar Nasional Sustainable Ergonomic For Better Human Well-Being, Universitas Atma Jaya Jogjakarta, 2015, pp. H25-H30.

21. Xiongjun, Y., Kaiqan, W., Study on Safety Management of Small and Medium-sized Enterprises Based on BBS, International Symposium on Safety Science and Technology, Procedia Engineering, 45, 2012, pp. 208-213. 